\title{
The Potential of a Hybrid Power Plant for the Dubrovnik - Neretva County (Southern Croatia)
}

\author{
Huili Zhang $^{*}$, Jan Baeyens ${ }^{2}$, Jan Degreve ${ }^{3}$ \\ ${ }^{1}$ Department of Chemical Engineering, Chemical and Biochemical Process Technology and Control \\ Section, KU Leuven, Heverlee, Belgium \\ e-mail: Zhanghl.lily@gmail.com \\ ${ }^{2}$ College of Life Science and Technology, Beijing University of Chemical Technology, Beijing, China \\ ${ }^{3}$ KU Leuven, Heverlee, Belgium
}

Cite as: Zhang, H., Baeyens, J., Degreve, J., The Potential of a Hybrid Power Plant for the Dubrovnik - Neretva County, J. sustain. dev. energy water environ. syst., 3(2), pp 174-182, 2015, DOI: http://dx.doi.org/10.13044/j.sdewes.2015.03.0014

\begin{abstract}
The Croatian electricity demand exceeds domestic production and about $30 \%$ of additional power is covered from imports. The Croatian government is planning to add domestic production capacity, using natural gas and coal as the main fuel. Due to the attractive solar irradiation in Croatia, these new projects offer the possibility to build these thermal power plants as hybrid plants by adding solar energy within the production. The present paper will investigate the potential of solar energy in the Southern Croatian region and its possible contribution in a hybrid set-up. The paper assesses the required input data and presents a hybrid Concentrated Solar Power (CSP) design. The results demonstrate the potential of adding a CSP in a hybrid power plant in Southern Croatia.
\end{abstract}

\section{KEYWORDS}

Croatia, Concentrated solar power, Design, Hourly direct irradiation, Plant simulation.

\section{INTRODUCTION}

Croatia has a total installed electricity generation capacity of 3,763 MW, including 2,097 MW of hydropower and 1,666 MW from thermal power plants (including a nuclear power plant, jointly owned with Slovenia) [1]. The domestic demand exceeds domestic production and about $30 \%$ of additional power is covered from imports. The Croatian government intends to restructure, liberalize and privatize the energy sector to emphasize compatibility with the European Union, whilst also planning to increase the domestic production capacity, especially with natural gas and coal as the fuel [2]. For Southern Croatia, the installation of an $800 \mathrm{MW}$ coal-fired power plant at Ploče is proposed, albeit severely opposed by eco-activists $[3,4]$. The main concerns relate to the potential of the Neretva river valley for ecological food production, to the possible pollution of the river, to the emission of hazardous pollutants (mainly fine dust) and to the negative impact of such a power plant upon the tourism in the region. The thermal power plant will moreover necessitate the transport of hundreds of tons of coal per day. Although modern coal-fired thermal power plants implement highly efficient techniques for dust abatement and for the reduction of common pollutants (e.g. $\mathrm{SO}_{2}$ ), the $\mathrm{CO}_{2}$ emissions of a coal-fired power plant remain a major issue. Unless an expensive $\mathrm{CO}_{2}$ capture is foreseen and depending on the quality of the coal, $\mathrm{CO}_{2}$ emissions will vary between 0.5 and 1 ton $\mathrm{CO}_{2} / \mathrm{MWh}$.

\footnotetext{
* Corresponding author
} 
As elsewhere, public concern, mostly about adding coal-fired power plants, has generated uncertainty in the electricity market, whilst creating a very favorable context towards new Renewable Energy projects, with a focus on using solar energy [5-7].

In March 2007, the European Union targeted 20\% renewable energy for 2020, with special emphasis on small scale units.

Due to the attractive solar irradiation in Southern Croatia, new power plant projects offer the possibility to build them as hybrid plants by adding solar energy within the production. Such a hybrid solution, where solar energy will partly replace the coal resource, will not only reduce the pollutant emissions (including $\mathrm{CO}_{2}$ ), but will moreover create an additional tourist attraction pole, as is the case with the Gemasolar solar power plant in Southern Spain [8]. An additional advantage results from the fact that the power block (boiler, turbines) will be available within the thermal power plant, thus only the investment in heliostats, solar receiver and heat carrier circuits need to be considered.

The present paper investigates the potential of solar energy in the Southern Croatian Dubrovnik-Neretva county and its possible contribution in a hybrid set-up. Such a hybrid solution of a traditional fossil fuel fired thermal power plant with a supply of solar energy during the daytime and during the night time if thermal energy storage is foreseen, will certainly create a more positive assessment by the public in comparison with a sole fossil fuel power plant.

To enhance the rate of this solar energy development, it is necessary to update the insights, the tools and the technical/economic analysis. Within the solar energy technologies, photovoltaics (PV) to a large extent and Concentrated Solar Power technology to a lesser extent, have been widely investigated and applied. PV draws a significant focus with a guaranteed future in view of the ongoing technical improvements and cost reduction [7, 9, 10]. Concentrated Solar Power Plants are gaining increasing interest, mostly by using the Parabolic Trough Collector (PTC) system, but with Solar Tower Collectors (STC) progressively occupy a significant market position. The large-scale STC technology was successfully demonstrated by Torresol in the Spanish Gemasolar project on a $19.9 \mathrm{MW}_{\mathrm{el}}$ scale [8]. The varying solar radiation flux throughout the day and throughout the year remains a main problem for all solar energy technologies. A more efficient operation requires the incorporation of two technologies, i.e. Thermal Energy Storage (TES) to cover non-sunny periods and Backup Systems (BS) or Hybrid Operation when solar energy or TES supply are not available. The combination of both systems facilitates a successful continuous and year round operation. To determine the optimum design and operation of the CSP throughout the year, whilst additionally defining the capacity of TES and required BS, an accurate estimation of the daily solar irradiation is needed, accounting for hourly irradiation fluxes and direct irradiation, since a CSP plant will only accept Direct Normal Irradiance (DNI) in order to operate.

Most of the countries, except those above latitude $45^{\circ} \mathrm{N}$ or below latitude $45^{\circ} \mathrm{S}$, are subject to an annual average irradiation flux in excess of $1.6 \mathrm{MWh} / \mathrm{m}^{2}$ [6]. The procedure, outlined in the present paper, combines previous theoretical and experimental findings into a general method of calculating the hourly beam (direct) irradiation flux and applying it to the design of CSP applications.

The present paper will hence:

- Briefly review the CSP technologies and their advantages;

- Estimate the hourly beam irradiation flux from available monthly mean global irradiation data for 2 selected European locations, being Sevilla as reference for the Gemasolar project [8] and Dubrovnik, as reference for the Dubrovnik-Neretva County;

- Select an appropriate plant configuration and perform a preliminary design; 
- Estimate the Levelized Electricity Cost for the hybrid potential in Southern Croatia.

\section{CSP TECHNOLOGIES}

Concentrated Solar Power (CSP) generates electricity by using heat provided by concentrated solar irradiation. Zhang et al. [6] reviewed available CSP technologies, including Parabolic Trough Collector (PTC), Solar Power Tower (SPT), Linear Fresnel Reflector (LFR), Parabolic Dish Systems (PDS) and Concentrated Solar Thermo-electrics (CSTe). Sunlight is reflected to a receiver (either a tower in SPT or focus heat capture pipes in PTC), where heat is collected by a thermal energy carrier (primary circuit) and mostly used via a secondary circuit to power a turbine. PTC and SPT have been built and developed around the world since 1981, with capacities ranging from 0.5 MW to more than $300 \mathrm{MW}$ [6]. Additional large-scale CSPs (2014-2017) will have capacities of 100's $\mathrm{MW}_{\mathrm{el}}$.

Short-term, direct Thermal Energy Storage stores excess heat collected in the solar field by the Heat Transfer Fluid (HTF), thus avoiding losing the daytime surplus energy while extending the production after sunset. Long term thermal energy storage is less obvious, since it involves storage covering months of low solar irradiation. Currently, only sensible heat is stored. The significant improvement by using latent heat storage (phase change materials) or even chemical heat storage (reversible endothermic/exothermic synthesis) is under development [11-13]. In current TES, liquids (oils, molten salts) are used for sensible heat capture and storage. Indirect storage uses solid heat absorbers and a secondary HTF circuit. SPT plants commonly use a BS to regulate production and guarantee a nearly constant capacity. The reference Gemasolar CSP uses molten salts $\left(<565{ }^{\circ} \mathrm{C}\right)$, a steam boiler and advanced Rankine cycle turbine. After discounting the parasitic energy use (mostly molten salt circulation, storage and boiler), the resulting conversion efficiency is about $16 \%$. With novel HTF materials, such as powders, the temperature range will be extended to well above $750{ }^{\circ} \mathrm{C}$, with reduced parasitic energy use and an expected overall conversion around 20\% [14-17]. The measures to enhance the efficiency of CSP plants are in full development. The Ploče initiative could certainly benefit from the expected conversion increase of 20 to $25 \%$.

\section{COMPUTING GLOBAL AND DIRECT SOLAR HOURLY IRRADIATION}

\section{Calculation method}

The equations and sequence of the calculation method were presented by Zhang et al. [6] and applied to the design of a CSP plant in Chile [18] and to the assessment of current photovoltaic initiatives [7]. The essential steps involve known data, general assumptions and a calculation sequence. The basic data include:

- The angle and distance of the sun vs. position on earth as function of latitude and time;

- Satellite data of monthly average solar irradiation $H$ [19];

- Data on temperatures, rainfall, wind speed;

- Day of the year, sunrise/sunset time. The calculation sequence involves calculating:

- The solar extra-terrestrial irradiation, $H_{0}$;

○ The average clearness index $K_{\mathrm{T}, \mathrm{av}}\left(=H / H_{0}\right.$, or via Hargreaves [20]), daily $K_{\mathrm{T}}$, and daily total irradiation $=K_{\mathrm{T}} H_{0}$;

○ The sequence of days (not needed with Hargreaves $K_{\mathrm{T}}$ );

○ The daily diffuse irradiation $H_{\mathrm{d}}$ as fraction of $H$; 
○ Predicting the hourly values of total $I / H$, diffuse $I_{\mathrm{d}} / H$ and direct (beam) irradiation $I_{\mathrm{b}}=I-I_{\mathrm{d}}$.

\section{Model parameters and selected locations}

There are two reliable sources that provide information on essential meteorological parameters: monthly mean temperature and solar radiation. These sources are the NASA website [19] with respect to solar radiation data and TUTIEMPO [21] to provide daily mean, maximum and minimum temperature data for any given location. The NASA data are available on a mean-monthly basis, whereas TUTIEMPO are downloadable on a day-by-day basis. It is important to remember that NASA data are based on satellite observations that represent inferred values of irradiation; in contrast, TUTIEMPO provides ground-measured data for temperature. Hence, if reliable regressions are available between irradiation and mean temperature, then the latter data may be used to obtain more realistic estimates of irradiation [6].

To illustrate the use of the methodology, two European locations were selected, i.e. Sevilla as a reference, since it is close to the Gemasolar STP and Dubrovnik as focal point of the Dubrovnik-Neretva County. The essential data of the locations are given in Table 1.

Table 1. Selected locations with basic data $[19,21]$

\begin{tabular}{cccccccccc}
\hline Location & $\begin{array}{c}\text { Latitude } \\
{[\mathrm{rad}]}\end{array}$ & $\begin{array}{c}\text { Longitude } \\
{[\mathrm{rad}]}\end{array}$ & $\begin{array}{c}\bar{H}(\mathrm{January}) \\
{\left[\mathrm{kWh} / \mathrm{m}^{2} \text { day }\right]}\end{array}$ & $\begin{array}{c}\bar{H}(\mathrm{July}) \\
{\left[\mathrm{kWh} / \mathrm{m}^{2} \text { day }\right]}\end{array}$ & $\begin{array}{c}T_{\max } \\
{\left[{ }^{\circ} \mathrm{C}\right]}\end{array}$ & $\begin{array}{c}T_{\min } \\
{\left[{ }^{\circ} \mathrm{C}\right]}\end{array}$ & $\begin{array}{c}T_{\max } \\
{\left[{ }^{\circ} \mathrm{C}\right]}\end{array}$ & $\begin{array}{c}T_{\min } \\
{\left[{ }^{\circ} \mathrm{C}\right]}\end{array}$ \\
\hline $\begin{array}{c}\text { Sevilla, } \\
\text { Spain }\end{array}$ & 37.41 & -5.98 & 2.56 & 7.80 & 15.9 & 7.6 & 35.7 & 19.9 \\
\hline $\begin{array}{c}\text { Dubrovnik, } \\
\text { Croatia }\end{array}$ & 42.65 & 18.09 & 1.61 & 5.96 & 10.1 & 2.9 & 31.3 & 22.2 \\
\hline
\end{tabular}

\section{RESULTS AND DISCUSSION}

\section{Direct irradiation}

The monthly extra-terrestrial irradiation, $H_{0}$ is a function of the latitude only, and for Dubrovnik ranging from $\sim 11.5 \mathrm{kWh} / \mathrm{m}^{2}$ day in June to $\sim 3.8 \mathrm{kWh} / \mathrm{m}^{2}$ day in December.

To proceed with the calculation of the monthly average clearness index, $\overline{K_{T}}, H_{0}$ is used together with NASA data [19]. Results are illustrated as example in Figure 1 for the Dubrovnik location.

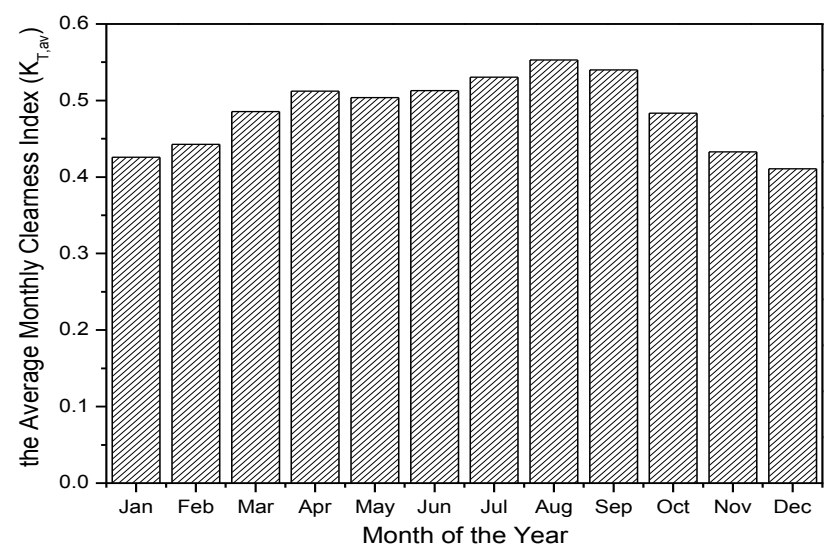

Figure 1. Calculated monthly average clearness index for Dubrovnik 
The daily total irradiation is thereafter obtained by applying the daily clearness index $K_{\mathrm{T}}$. Figure 2 shows the model-predicted total daily irradiation, ordered in ascending daily pattern for Dubrovnik for a summer month (July) and a winter month (January). The monthly average $H$ in January and July, are $1.67 \mathrm{kWh} / \mathrm{m}^{2}$ day and $5.92 \mathrm{kWh} / \mathrm{m}^{2}$ day, respectively. Similar trends are obtained for Sevilla.

Applying the sequence model for the daily clearness indexes, as function of $K_{\mathrm{T}}$ [6], transforms the ascending nature of the consecutive days into a wave-function, although monthly average values of $H$ remain unchanged.

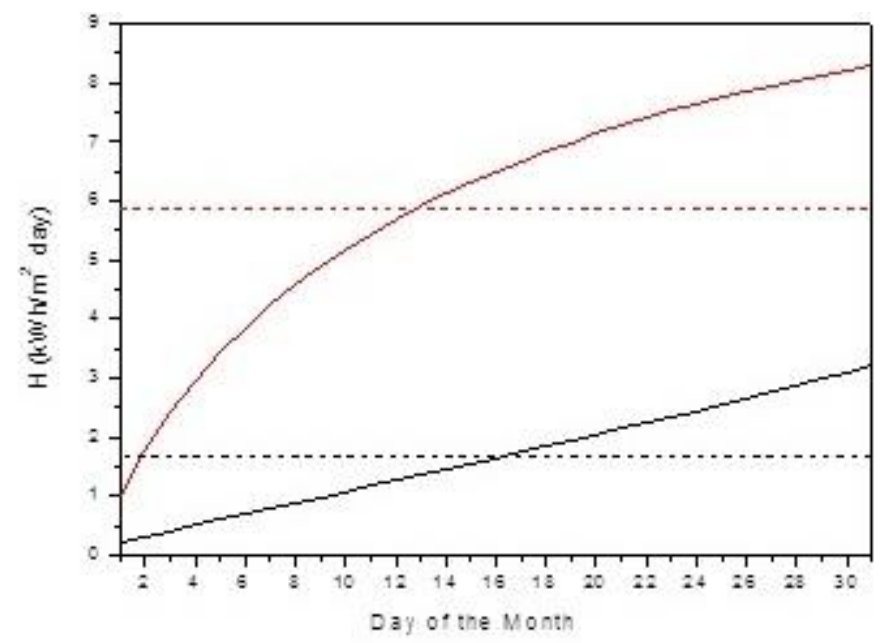

Figure 2. The total daily irradiation in Dubrovnik: - - - average; — ascending pattern (- - - - in January and - - , - - in July)

The most important result towards CSP design requires the direct (beam) irradiation, obtained by subtracting the diffuse irradiation, $H_{\mathrm{d}}$, from the total irradiation $H$. The ratio of the diffuse to total irradiation in Dubrovnik is $\sim 0.5$ in August and $\sim 0.66$ in December.

The resulting beam radiation $H_{\mathrm{b}}$, as detailed daily/monthly average values for Dubrovnik and reference Sevilla, is shown in Figure 3.

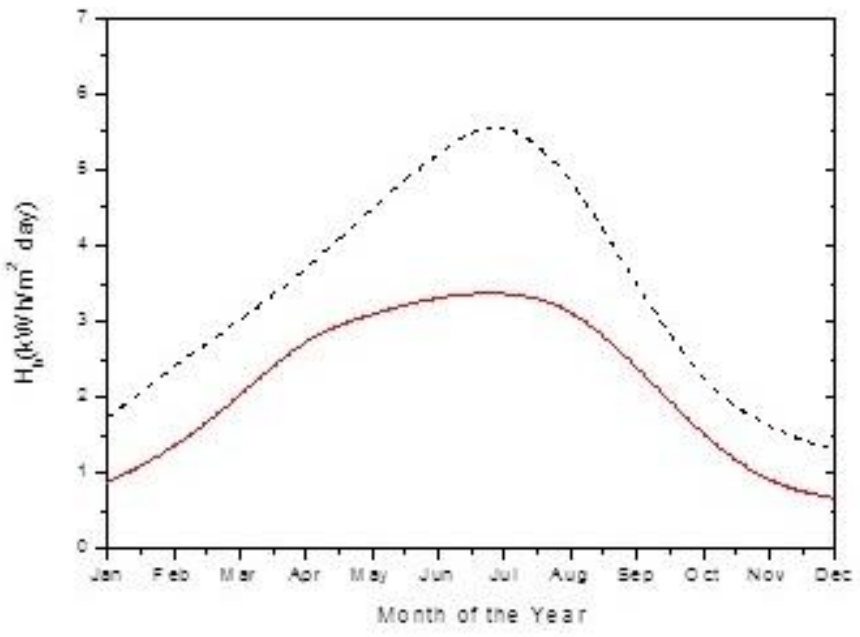

Figures 3. Average monthly direct (beam) irradiation: - - - in Sevilla; — in Dubrovnik

Due to its lower latitude, Sevilla presents much higher values of $H_{\mathrm{b}}$ than Dubrovnik. Finally, a complete hourly profile can be predicted by the model, as illustrated in Figure 4, where the radiation flux can be seen to increase from sunrise to noon, and thereafter decreasing again till sunset. 
Figure 3 also implies that the selection of the CSP nominal capacity will be a compromise between the seasons, accounting for the capability of thermal storage, and the use of a backup system.

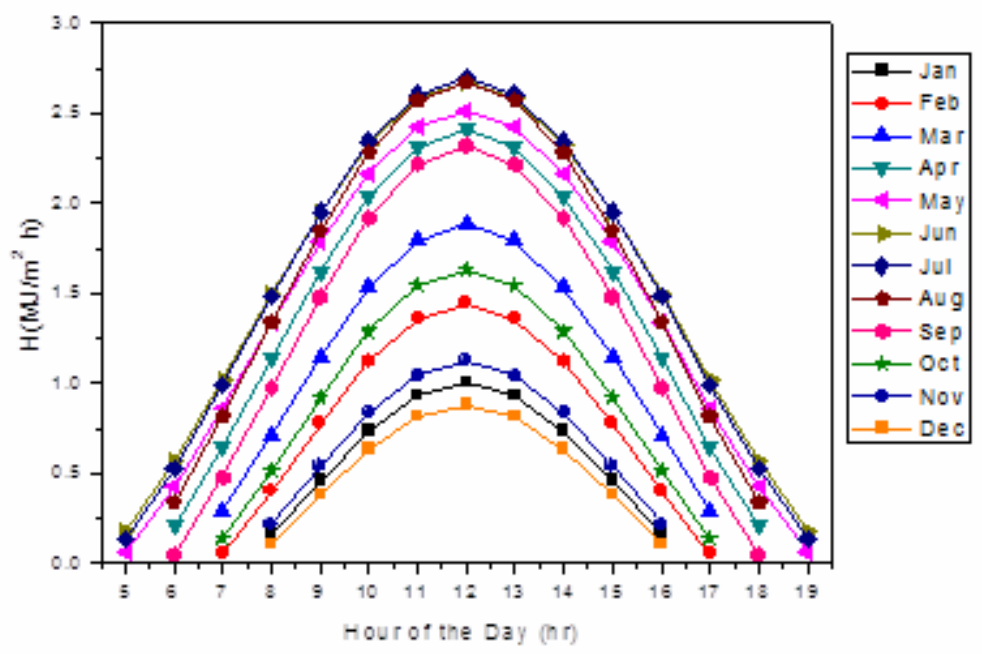

Figure 4. Hourly values on the $15^{\text {th }}$ of the respective months in Dubrovnik

\section{Methodology to apply the predictions in CSP design}

Having established the annual, monthly and daily levels of direct (beam) solar irradiation, its impact on the power yield of the CSP plant can be assessed.

To do so, it should be remembered that the overall CSP-layout has its overall efficiency. The projected overall efficiency of CSP plants currently exceeds $16 \%$ and is expected to reach $\geq 20 \%$ by $2020[6,18,22]$. The current efficiencies of the essential components have been reported by Sargent and Lundy Consulting Group [22].

Considering the application of the Solar Tower Collector, with molten salt HTF/TES and with natural gas or coal-fired BS, and assuming the use of a heliostat field (HFC) of $318,000 \mathrm{~m}^{2}$ (as applied by Gemasolar), Figure 5 provides some indications of the simulated results.

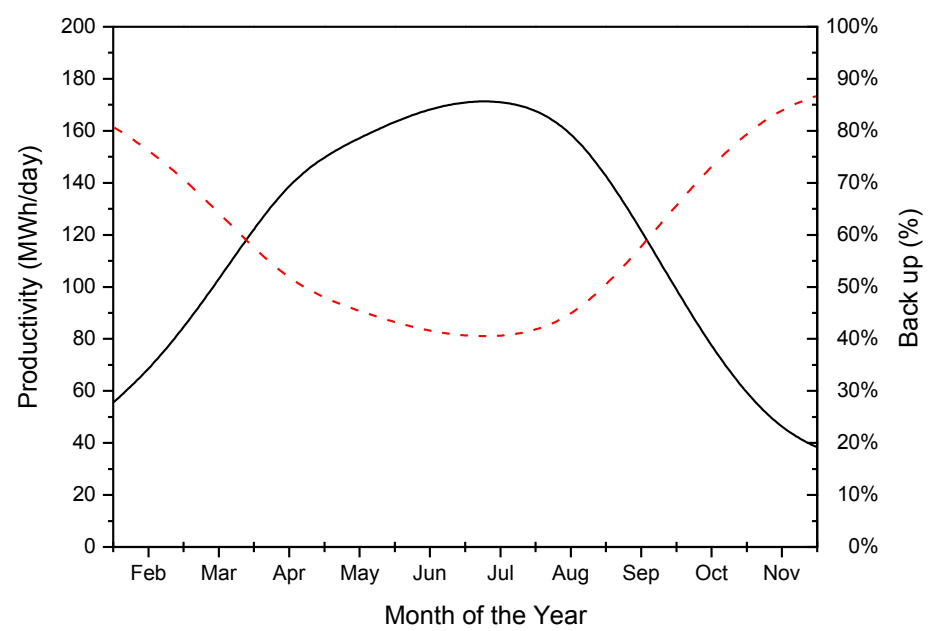

Figure 5. Electricity Generation (at an overall $16 \%$ conversion) throughout the year in the possible Dubrovnik-Neretva SPT, in hybrid operating mode: - solar production; - - - back up requirements

It is understood that the annual shut-down/maintenance period will be between December $15^{\text {th }}$ and January $15^{\text {th }}$. The results of the simulation for the Dubrovnik-Neretva 
initiative reveal that the solar generation will account for $\sim 36 \mathrm{GWh} /$ year, in the case of a conservative $16 \%$ overall efficiency. At $20 \%$ efficiency, as can be expected for the Dubrovnik-Neretva plant using newest technologies, the production will increase to 45 GWh/year. The back-up requirements in the Dubrovnik-Neretva case are intrinsically available through the coal-fired thermal power plant.

In locations with higher solar irradiation, e.g. Gemasolar [8] or Calama [18], the solar energy contribution will be proportionally enhanced.

To significantly increase the solar contribution for the Dubrovnik-Neretva power plant, the size of the HFC will need to be increased.

\section{Levelized Energy Cost}

A further demonstration of the SPT potential for Dubrovnik-Neretva is provided by a tentative Levelized Energy Cost (LEC) calculation, commonly used to compare competing energy sources and expressed in USD $/ \mathrm{kWh}$. The total investment includes the costs of the solar field and of the TES. Since the proposed plant will be of hybrid nature, the costs related to the coal-fired BS and associated cooling process, were not included in the calculation.

Economic factors from literature were used, as summarized in Càceres et al. [18]. A $10 \%$ discount rate and 25 years life time of the plant were used.

At a pessimistic overall efficiency of $16 \%$, LEC-values for the sole solar energy contribution vary between 0.10 and $0.12 \mathrm{USD} / \mathrm{kWh}$. An enhanced overall efficiency (16 to $20 \%$ ) will reduce the LEC proportionally. These LEC results are consistent with literature references for solar energy prices. The technical and economic potential of the Dubrovnik-Neretva hybrid SPT project is certainly significant, and reduces the environmental burden of a sole coal-fired power plant. Costs of solar field and power block are moreover decreasing, which will positively affect the LEC-value. The introduction of powder circulation heat carriers and Phase Change Materials is also expected to significantly reduce the LEC $[12,13,16]$.

\section{CONCLUSIONS}

The paper develops the underlying equations to calculate the daily total irradiation, the direct (beam) and diffuse irradiation. Having established the annual, monthly and daily levels of direct (beam) solar irradiation, its impact on the power yield of the CSP can be assessed. The projected overall efficiency of CSP plants was included in a CSP performance simulation. Initial simulation results are illustrated for a $12 \mathrm{MW}_{\mathrm{el}}$ Solar Power Tower project, with molten salts as HTF and operating in a hybrid way with the projected coal-fired thermal power plant at Ploce, in the Dubrovnik-Neretva County. In the assessed example, solar generation will account for $\sim 45 \mathrm{GWh} /$ year, with possible higher yields due to improvements in HFC, solar tower design and reduced parasitic electricity consumption. The results demonstrate the potential of adding a CSP in a hybrid operation of the coal-fired power plant of Ploče.

\section{NOMENCLATURE}

$\begin{array}{lll}H_{0} & \begin{array}{l}\text { Extra-terrestrial radiation } \\ \text { Daily total radiation obtained from the registered } \\ \text { measurements }\end{array} & {\left[\mathrm{kWh} / \mathrm{m}^{2} \text { day }\right]} \\ \bar{H} & \begin{array}{l}\text { Monthly average of } H \\ {\left[\mathrm{kWh} / \mathrm{m}^{2} \text { day }\right]}\end{array} & {\left[\mathrm{kWh} / \mathrm{m}^{2} \text { day }\right]} \\ I, I_{\mathrm{d}}, I_{\mathrm{b}} & \begin{array}{l}\text { Hourly solar radiation, } \\ \text { with diffuse and beam components, respectively }\end{array} & {\left[\mathrm{MJ} / \mathrm{m}^{2} \mathrm{~h}\right]}\end{array}$




$\begin{array}{lll}K_{\mathrm{T}, \mathrm{av}} & \text { Monthly average clearness index } & {[-]} \\ K_{\mathrm{T}} & \text { Daily clearness index } & {[-]}\end{array}$

\section{Abbreviations}

$\begin{array}{ll}\text { BS } & \text { Backup System } \\ \text { CSP } & \text { Concentrated Solar Power Plant } \\ \text { CSTe } & \text { Concentrated Solar Thermo-electrics } \\ \text { DNI } & \text { Direct Normal Irradiance } \\ \text { HFC } & \text { Heliostat Field Collector } \\ \text { HTF } & \text { Heat Transfer Fluid } \\ \text { LEC } & \text { Levelized Electricity Cost } \\ \text { LFR } & \text { Linear Fresnel Reflector } \\ \text { PDS } & \text { Parabolic Dish System } \\ \text { PTC, STC } & \text { Parabolic Trough Collector; Solar Tower Collector, respectively } \\ \text { PV } & \text { Photovoltaics } \\ \text { SPT } & \text { Solar Power Tower } \\ \text { TES } & \text { Thermal Energy Storage }\end{array}$

\section{REFERENCES}

1. HEP, Croatia, http://www.hep.hr/ops/en/hees/data:aspx

2. National Energy Grid Croatia, www.geni.org/globalenergy/librang/national_energy_grid/Croatia/EnergyOverviewo fCroatia

3. Croatian Times, Eco Activists oppose Plans to build a Power Plant near Ploce, www.croatiantimes.com, 05 June 2014.

4. Neretva Valley, Metkovic Mayor against Thermal Power Plant in Neretva Valley, www.dalje.com, [Accessed: 01-March-2014]

5. OECD/IEA, Technology Roadmap, Concentrating Solar Power, 2010.

6. Zhang, H. L., Baeyens, J., Degrève, J., Cacères, G., Concentrated Solar Power Plants: Review and Design Methodology, Renewable and Sustainable Energy Reviews, Vol. 22, pp 466-481, 2013, http://dx.doi.org/10.1016/j.rser.2013.01.032

7. Zhang, H. L., Van Gerven, T., Baeyens. J. and Degrève, J., Photovoltaics: Reviewing the European Feed-in-Tariffs and Changing PV Efficiencies and Costs, The Scientific World Journal, 404913, pp 1-10, 2014, http://dx.doi.org/10.1155/2014/404913

8. http://www.torresolenergy.com/TORRESOL/gemasolar-plant/en

9. EPIA, Connecting the Sun, Solar Photovoltaics on the Road to Large-Scale Grid Integration, September 2012.

10. Tyagi, V. V., Rahim, N. A. A., Rahim, N. A., Selvaraj, J. A. L., Progress in Solar PV Technology: Research and Achievement, Renewable and Sustainable Energy Reviews, Vol. 20, pp 443-461, 2013, http://dx.doi.org/10.1016/j.rser.2012.09.028

11.Fernandes, D., Pitié, F., Cáceres, G., Baeyens, J., Thermal Energy Storage "How previous findings determine current research priorities" Energy, Vol. 39, No. 1, pp 246-257, 2012, http://dx.doi.org/10.1016/j.energy.2012.01.024

12. Pitié, F., Zhao, C. Y., Baeyens, J., Degrève, J., Zhang, H. L., Circulating Fluidized Bed Heat Recovery/storage and its Potential to use Coated Phase-change-material (PCM) Particles, Applied Energy, Vol. 109, pp 505-513, 2013, http://dx.doi.org/10.1016/j.apenergy.2012.12.048

13.Zhang, H. L., Baeyens, J., Degrève, J., Cáceres, G., Segal, R., Pitié, F., Latent Heat Storage with Tubular-encapsulated Phase Change Materials (PCMs), Energy, (in press), 2014, http://dx.doi.org/10.1016/j.energy.2014.03.067 
14.Zhang, H. L., Baeyens, J., Degrève, J., Brems, A., Dewil, R., The Convection Heat Transfer Coefficient in a Circulating Fluidized Bed (CFB), Advanced Powder Technology, Vol. 25, No. 2, pp 710-715, 2014, http://dx.doi.org/10.1016/j.apt.2013.10.018

15.Zhang, H. L., Flamant, G. , Gauthier, D., Ansart, R., Hemati, M., Baeyens, J., Boissière, B., The use of Dense Particle Suspensions as Heat Transfer Carrier in Solar Thermal Plants, International Conference on Solar Heating and Cooling, pp 25-27, June 2014, Gleisdorf, Austria.

16. Flamant, G., Gauthier, D., Benoit, H., Sans, J. L., Garcia, R., Boissière, B., Ansart, R., Hemati, M., Dense Suspension of Solid Particles as a new Heat Transfer Fluid for Concentrated Solar Thermal Plants: On-sun Proof of Concept, Chemical Engineering Science, Vol. 102, pp 567-576, 2013, http://dx.doi.org/10.1016/j.ces.2013.08.051

17. Barlev, D., Vidu, R., Stroeve, P., Innovation in Concentrated Solar Power, Solar Energy Materials \& Solar Cells, Vol. 95, No. 10, pp 2703-2725, 2011, http://dx.doi.org/10.1016/j.solmat.2011.05.020

18. Cáceres, G., Anrique, N., Girard, A., Degrève, J., Baeyens, J., Zhang, H. L., Performance of molten Salt Solar Power Towers in Chile, Journal of Renewable and Sustainable Energy, Vol. 5, 053142, 2013, http://dx.doi.org/10.1063/1.4826883

19. NASA, http://eosweb.larc.nasa.gov/cgi-bin/sse/retscreen.cgi?email=rets@ nrcan.gc.ca

20. Hargreaves, G., Simplified Coefficients for estimating Monthly Solar Radiation in North America and Europe, Dept. paper, Department of Biology and Irrigation Engineering, Utah State University, 1994.

21. Tutiempo, http://www.tutiempo.net/en/

22. Sargent and Lundy Consulting Group, Assessment of Parabolic Trough and Power Tower Solar Technology Cost and Performance Forecasts, National Renewable Energy Laboratory, 2003. 